\author{
Сахно $^{-1}$ В.П., Ященко ${ }^{-1}$ Д.М., І.С , Диких ${ }^{-1}$ О.В., Стельмащук² В.В., Онищук ${ }^{2}$ В.П. \\ ${ }^{-1}$ Національний транспортний університет \\ -2 Луиький начіональний технічний університет
}

\title{
ДО ВИБОРУ ТИПУ ДВИГУНА ПРИ МОДЕРНІЗАЦІЇ БТР-70
}

\begin{abstract}
В роботі розглянуті варіанти переобладнання БТР-70 шляхом встановлення на шасі цього автомобіля замість двох двигунів 3М3-4905 двох двигунів General Motors потужністю 103 кВт, або двох вигунів IVECO Tector P4 потужністю 110,4 кВт, або двох двигунів Д245.30Е2 потужністю 115 кВт, або двох двигунів різної потужності - потужність основного двигуна DEUTZ TCD 2013 L4 4V 161 кВт і потужність додаткового двигуна DEUTZ D 914L3 43 кВт. В основу порівняльного аналізу покладено основні показники тяговошвидкісних властивостей, що отримані шляхом розв'язку диференціального рівняння руху, вихідними даними для якого слугують масові та геометричні параметри автомобіля та умови експлуатації. Вибір кращого варіанту виконано на основі порівняння кожного показника тягово-швидкісних властивостей з еталоном, у якості якого прийнято кращий показник із усіх можливих варіантів. За результатами розрахунків встановлено, що показники тягово-швидкісних властивостей автомобіля 3 двигунами IVECO Tector P4, Д245.30Е2 і двома двигунами DEUTZ TCD 2013 майже однакові і змінюються від найбільшого значення (двигуни Д245.30Е2) до найменшого (два двигуни DEUTZ TCD 2013) в межах 4\%, не зважаючи на те, що їх потужність змінюється на 11,3\%. Тому вибір кращого типу двигуна при переобладнанні БТР-70 повинен проводитися з урахуванням інших показників, зокрема, паливної економічності.

Ключові слова: БТР-70, двигун, потужність, модернізація, показник, тягово-швидкісні властивості, еталон, диференціальне рівняння руху
\end{abstract}

\section{ВСТУП}

На виставці "Зброя і безпека-2018" крім абсолютно нових моделей і прототипів перспективних зразків озброєнь представлено і досить велика кількість варіантів модернізації старої радянської техніки. Це перш за все лінійка БМП (як БМП-1, так і БМП-2), а також бронетранспортери БТР-60 і БТР-70. Всі представлені зразки модернізації в тій чи іншій мірі унікальні, проте деякі варто виділити. Так, вельми радикальним видається варіант модернізації БТР-70 від Житомирського бронетанкового заводу. Нова бойова машина отримала назву БТР-70Д (GM). Щодо інформації по двигунам , то штатні бензинові двигуни ГАЗ 4905 були замінені на дизелі виробництва General Motors потужністю 103 кВт [1].

Сама ідея подібної модернізації техніки в Україні не нова і до початку бойових дій на Донбасі вже були вдало реалізовані проекти на ДП “Миколаївський бронетанковий завод" під назвою БТР7(БТР-70Ді) тоді штатні силові установки замінили двома двигунами FPT IVECO Tector P4 потужністю 150 к.с. кожний, що на 30 к.с. більше ніж в рідного двигуна марки ГАЗ. Також були і інші варіації ремоторизації машини, зокрема, вітчизняний ХБКМ ім. Морозова у середині 2000-х років представив БТР-70 3 встановленим двигуном вітчизняного виробництва УТД-20 на бронетранспортер [1].

Державний концерн "Укроборонпром", що об'єднує головні оборонні підприємства України, адаптував свою бронетехніку під натівський двигун Deutz (Німеччина) замість російських, постачання яких припинилося з початком військової агресії Росії на Донбасі [2]. При переобладанні спеціальної колісної техніки (СКТ) заміні підлягають, як правило, тільки двигуни базової машини.

Як при модернізації, так і при переобладнанні СКТ не до кінця вирішеним є питання потужності силової установки, яка задовольнила б усім вимогам, що висуваються до подібної техніки, зокрема, до показників тягово-швидкісних властивостей.

\section{АНАЛІЗ ЛІТЕРАТУРНИХ ДАНИХ ТА ПОСТАНОВКА ПРОБЛЕМИ}

Тягово-швидкісні властивості мають важливе значення при експлуатації автомобіля, оскільки вони безпосередньо пов'язані із середньою швидкістю руху та продуктивністю. Поліпшення тяговошвидкісних властивостей означає збільшення потенційної середньої швидкості та зменшення часових втрат перевезення вантажів, а також підвищення продуктивності автомобіля [3-6].

Ці властивості визначають динаміку розгону автомобіля, можливість розвивати ним максимальну швидкість, зменшувати час, необхідний для розгону автомобіля до певної швидкості.

Поліпшення тягово-швидкісних властивостей $\epsilon$ однією 3 основних тенденцій розвитку автомобілебудування, про що свідчать більш високі значення максимальної швидкості та прискорення кожного нового покоління автомобілів. Автомобіль 3 відносно кращими тягово- 
швидкісними властивостями в реальних дорожніх умовах має більший запас потужності, який дозволяє долати опір руху (сили опору коченню, повітря, підйому) без зменшення швидкості, або здійснювати розгін, більшу середню швидкість руху [3], проте до тепер немає загальної методики оцінки показників динамічності автомобіля.

У роботі [7] для вибору типу автомобіля-тягача для автопоїзда великої вантажопідйомності запропонована методика, що заснована на аналізі відомих показників тягово-швидкісних властивостей i вибором кращого із розглянутих, що присвоюється еталону. По відношенню до еталону встановлюються питомі показники для автопоїзда з різними автомобілями-тягачами, сума яких дає передумови для вибору кращого серед них, що може бути використано і в даній роботі.

\section{ЦІЛЬ ТА ЗАДАЧІ ДОСЛІДЖЕННЯ}

Ціль дослідження полягає у виборі типу двигуна при переобладнанні БТР-70 за показниками тягово-швидкісних властивостей. Для досягнення цілі дослідження вирішувалися такі задачі:

- вибір типу двигуна та побудова його швидкісної зовнішньої характеристики;

- вибір, обгрунтування та визначення показників тягово-швидкісних властивостей;

- вибір двигуна для БТР-70 за показниками порівняння його з еталонним автомобілем.

\section{РЕЗУЛЬТАТИ ДОСЛІДЖЕННЯ}

Розрахунок показників тягово-швидкісних властивостей автомобіля базується на його характеристиках та умовах експлуатації. При цьому порівняльний аналіз показників тяговошвидкісних властивостей проводиться для одного i того ж автомобіля 3 різними силовими установками. Такий аналіз проводиться, як правило, шляхом розв'язку диференціального рівняння руху, вихідними даними для якого слугують масові та геометричні параметри автомобіля та умови експлуатації, що наведені у роботі [8]. Зокрема, це повна маса автомобіля $\mathrm{Ga}=11900$ кг; коефіцієнт корисної дії трансмісії при роботі двох двигунів $\eta_{\mathrm{m} 2}=0,701$, при роботі тільки одного двигуна $\eta_{\mathrm{M} 1}=0,837$; фактор обтічності $k_{\mathrm{v}} \times \mathrm{F}=3,68 \mathrm{H} \times \mathrm{c}^{2} / \mathrm{M}^{2} ;$ коефіцієнт опору кочення $f_{\mathrm{v}}=0,015+0,012 \times(0,01 v)^{2,5}$, де $V$ - швидкість автомобіля, км/ год .

У цій же роботі розглянута можливість встановлення на автомобілі таких двигунів:

1 варіант - два двигуни ЗМЗ-4905 потужністю 120 к.с. (базовий варіант);

2 варіант - два двигуна General Motors потужністю 140 к.с. («Житомирський бронетанковий завод»);

3 варіант - два двигуни IVECO Tector P4 потужність 150 к.с. (ДП “Миколаївський бронетанковий завод”);

4 варіант - два двигуна Д245.30Е2 потужністю 115 кВт (приватна компанія “Техимпекс");

5 варіант два двигуна різної потужності - потужність основного двигуна 161 кВт і потужність додаткового двигуна 43 кВт (пропонований варіант).

У табл. 1 наведена коротка технічна характеристика пропонованих двигунів.

Таблиця 1 - Коротка технічна характеристика двигунів

\begin{tabular}{|c|c|c|}
\hline Тип двигуна & \multicolumn{2}{|l|}{ Максимальна потужність, } \\
кВт/ при частоті обертання хв
\end{tabular}

За відсутності експериментальних зовнішніх характеристик двигунів, табл.1, скористаємося методикою іiі побудови, наведеної у роботі [7], в якій показано, що максимальна похибка апроксимації кривої крутного моменту за параметрами максимального значення моменту і моменту при максимальній потужності для різних типів двигунів поліномом другого ступеня не перевищить $6 \%$. Тому у подальших розрахунках криву крутного моменту двигуна будемо апроксимувати поліномом другого ступеня виду

$$
M_{\kappa}=a \cdot \omega^{2}+b \cdot \omega+c
$$


де $a, b, c$ - сталі коефіцієнти, котрі визначають за допомогою інтерполяційної формули Лагранжа [9]:

$a=\frac{M_{e \min }}{A_{11}}+\frac{M_{e \max }}{A_{12}}+\frac{M_{e N}}{A_{13}}$,
$b=\left[\frac{\left(\omega_{N}+\omega_{M}\right) \cdot M_{e \min }}{A_{11}}+\frac{\left(\omega_{N}+\omega_{\min }\right) \cdot M_{e \max }}{A_{12}}+\frac{\left(\omega_{\min }+\omega_{M}\right) \cdot M_{e N}}{A_{13}}\right]$
$c=\left(M_{e \text { min }} \cdot \frac{\omega_{M} \cdot \omega_{N}}{A_{11}}+M_{e \max } \cdot \frac{\omega_{N} \cdot \omega_{\min }}{A_{12}}+M_{e N} \cdot \frac{\omega_{\min } \cdot \omega_{M}}{A_{13}}\right)$,

де $\mathrm{A}_{11}=\omega_{\min }^{2}-\omega_{\min }\left(\omega_{\mathrm{N}}+\omega_{\mathrm{M}}\right)+\omega_{\mathrm{N}} \cdot \omega_{\mathrm{M}}$;

$A_{12}=\omega_{M}^{2}+\omega_{M}\left(\omega_{N}+\omega_{\text {min }}\right)+\omega_{N} \cdot \omega_{\text {min }}$;

$\mathrm{A}_{13}=\omega_{\mathrm{N}}^{2}+\omega_{\mathrm{N}}\left(\omega_{\mathrm{M}}+\omega_{\min }\right)+\omega_{\mathrm{M}} \cdot \omega_{\min }$;

$\omega_{\min }, \mathbf{M}_{\text {к.min }}-$ мінімальна кутова швидкість колінчастого валу двигуна, рад/с, та крутний момент, Н·м, при цій кутовій швидкості;

$\mathrm{M}_{\text {к.max }}, \omega_{\mathrm{M}}-$ максимальний крутний момент двигуна, Н·м, та кутова швидкість колінчастого валу двигуна, рад/с, що йому відповідає;

$\mathrm{M}_{\mathrm{N}}, \omega_{\mathrm{N}}-$ крутний момент, H·м, та кутова швидкість колінчастого валу двигуна, рад/с, що відповідають його максимальній потужності.

У табл. 2 наведені результати розрахунку апроксимуючих коефіцієнтів для двигунів, що розглядаються.

Таблиця 2 - Коефіцієнти апроксимуючого поліному

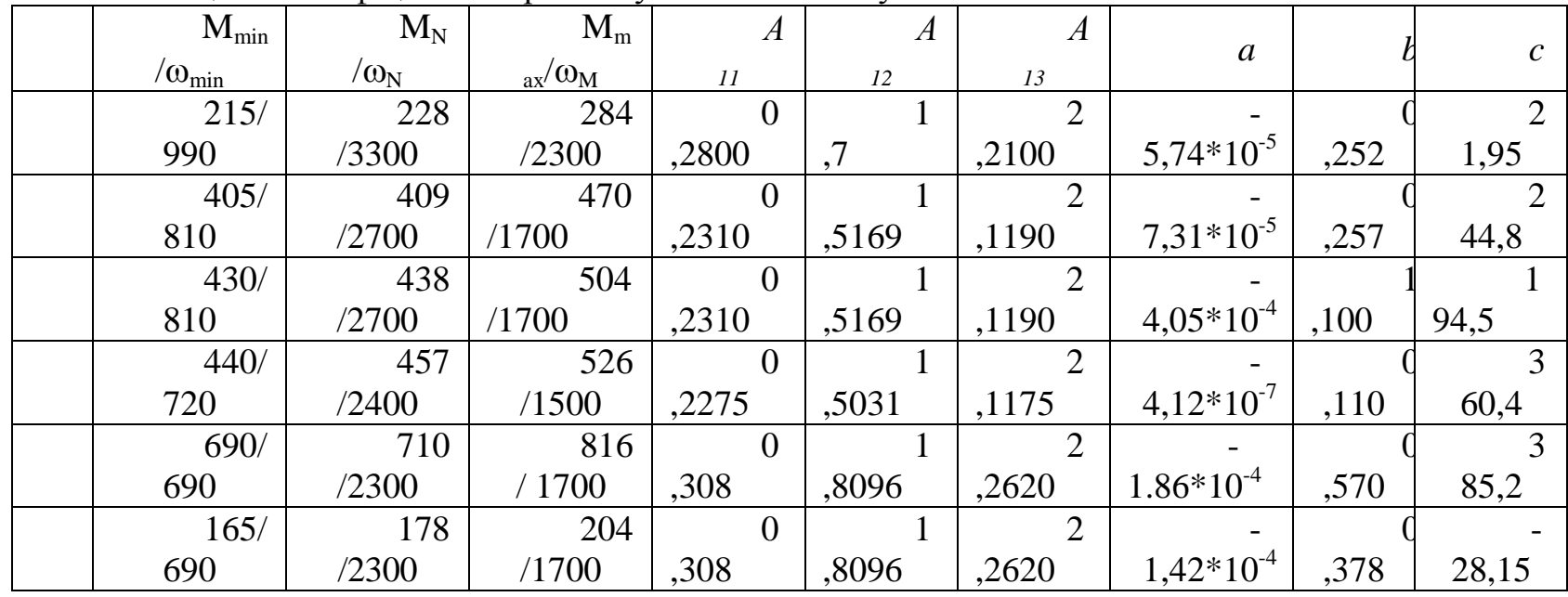

Похибка визначення максимального крутного моменту за рівнянням (1) не перевищує 1,5\%.

Визначення показників тягово-швидкісних властивостей автомобіля за різних типів двигуна виконаємо при незмінній трансмісії базового автомобіля $з$ параметрами: коробка передач - чотирьох ступенева 3 передаточними відношеннями передач: $\mathrm{u}_{\mathrm{k} 1}=6,65 ; \mathrm{u}_{\mathrm{k} 2}=3,09 ; \mathrm{u}_{\mathrm{k} 3}=1,71 ; \mathrm{u}_{\mathrm{k} 1}=1,00 ;$ додаткової коробки передач: $\mathrm{u}_{\mathrm{zk} 1}=1,00 ; \mathrm{u}_{\mathrm{zk} 2}=1,89$; головної передачі: $\mathrm{u}_{0}=1,846$; колісного редуктора $\mathrm{u}_{0 \mathrm{k}}=4,33$.

Диференціальне рівняння, яке використовується в теорії автомобіля, справедливе для прямолінійного руху і тому може бути використане для моделювання руху на ЕОМ в умовах визначення основних оцінних показників тягово-швидкісних властивостей [9]:

$$
\frac{\mathrm{dv}}{\mathrm{dt}} \mathrm{m}_{\mathrm{a}} \delta_{\text {об }}=\mathrm{P}_{\text {ко }}(\mathrm{v})-\mathrm{P}_{\mathrm{o}}\left(\mathrm{v}, \mathrm{v}^{2}\right) \pm \mathrm{G}_{\mathrm{a}} \sin \alpha
$$

де $\mathrm{m}_{\mathrm{a}}$ - маса автомобіля;

$\delta_{\text {об }}$ - коефіцієнт, що враховує обертові маси автомобіля;

$\mathrm{P}_{\text {ко }}(\mathrm{v})$ - повна колова сила на ведучих колесах автомобіля;

$\mathrm{P}_{\mathrm{o}}\left(\mathrm{v}, \mathrm{v}^{2}\right)$ - сума сил опору руху автомобіля, що залежать від швидкості його руху;

$\mathrm{G}_{\mathrm{a}} \sin \alpha-$ сила опору підйому; 
$\mathrm{G}_{\mathrm{a}}$ - сила тяжіння від повної маси автомобіля;

$\alpha$ - кут нахилу поверхні дороги;

$\mathrm{v}$ - швидкість руху автомобіля;

$\frac{\mathrm{dv}}{\mathrm{dt}}$ - прискорення автомобіля.

Зважаючи на те, що аналітичну функцію для сили $\mathrm{P}_{\text {ко }}(\mathrm{v})$ точно визначити неможливо, зазначене диференціальне рівняння (1) другого порядку із сталими коефіцієнтами є таким, що в загальному випадку не інтегрується. Проте його інтегрування можна провести, якщо вважати, що функція $\mathrm{P}_{\text {ко }}(\mathrm{v})$ задана або визначена, наприклад, коли розглядати роботу двигуна за швидкісною зовнішньою характеристикою.

Повна колова сила на ведучих колесах автомобіля $P_{\text {ко }} 3$ достатньою для практичних розрахунків точністю і з урахуванням умов експлуатації може визначатися з формули тягової сили [9]:

$$
P_{K O} \approx P_{T}=\frac{M_{K} U_{T} \eta_{m}}{\tau_{\partial}},
$$

де $M_{\text {к }}$ момент двигуна;

$U_{\mathrm{T}}$ - загальне передаточне число трансмісії;

$\eta_{\mathrm{m}}-$ ККД трансмісії тягача;

$r_{d}$ - динамічний радіус колеса.

Таким чином, для отримання залежності $P_{\text {ко }}=f(V)$ вихідними даними послуговують залежність $M_{\text {к }}=f(\omega)$, яку отримують із швидкісної зовнішньої характеристики двигуна, та рівняння зв'язку між швидкістю руху та кутовою швидкістю колінчастого валу двигуна:

$$
V=\frac{\omega r_{\kappa}}{U_{T}}
$$

3 урахуванням залежностей $M_{\mathrm{K}}=f(\omega)$ та $V=f(\omega)$ тягова сила на ведучих колесах визначиться:

$$
P_{T}=A_{i} V^{2}+B_{i} V+C_{i},
$$

де $A_{i}=a \frac{U_{i}^{3} \eta_{m}}{r_{\partial} r_{\kappa}^{2}}, \quad B_{i}=b \frac{U_{i}^{2} \eta_{m}}{r_{\partial} r_{\kappa}}, \quad C_{i}=c \frac{U_{i} \eta_{m}}{r_{\partial}}$,

$U_{\mathrm{i}}$ - передаточне відношення трансмісії на і-ій передачі за прямої передачі у додатковій коробці передач: $\mathrm{u}_{1}=53,15 ; \mathrm{u}_{2}=24,7 ; \mathrm{u}_{3}=13,67 ; \mathrm{u}_{4}=7,99$.

Коефіцієнт обертових мас АТЗ $\delta_{\text {об }}$, що входить у рівняння (1), визначається із виразу

$$
\delta_{\text {об }}=1+\sigma_{1} \times u_{k i}^{2}+\sigma_{2}
$$
$03 \ldots 0,05$

де $\sigma_{1}, \sigma_{2}$ - сталі коефіцієнти, які для автомобіля, що розглядається, знаходяться в межах - 0 ,

Динамічний радіус колеса (в першому наближенні) дорівнює статичному радіусу [10], тобто $r_{\partial}$ $=r_{c}$ i для шин 340/80R 18 складає 0,465 м.

$\mathrm{У}$ табл. 3 наведені значення коефіцієнтів $\mathrm{A}_{\mathrm{i}}, \mathrm{B}_{\mathrm{i}}, \mathrm{C}_{\mathrm{i}}$ для вищої передачі в додатковій коробці передач автомобіля з двигунами, що розглядаються. 
() Сахно В.П., Ященко Д.М., Диких О.В., Стельмащук В.В., Онищук В.П. 2020

Таблиця 3 - Коефіцієнти $\mathrm{A}_{\mathrm{i}}, \mathrm{B}_{\mathrm{i}}, \mathrm{C}_{\mathrm{i}}$ для вищої передачі в додатковій коробці передач автомобіля 3 двигунами, що розглядаються

\begin{tabular}{|c|c|c|c|c|c|c|c|}
\hline \multirow{2}{*}{ Двигун } & \multicolumn{3}{|c|}{$\begin{array}{c}\text { Коефіцієнти апроксимуючого } \\
\text { поліному двигуна }\end{array}$} & \multicolumn{4}{|c|}{ Коефіцієнти для усіх передач } \\
\hline & $a$ & $b$ & $c$ & передача & $A_{i}$ & $B_{i}$ & $C_{i}$ \\
\hline 1 & $-5,74 * 10^{-5}$ & 0,252 & 21,95 & $\begin{array}{l}1 \\
2 \\
3 \\
4\end{array}$ & $\begin{array}{l}-60,09 \\
-6,03 \\
-1,02 \\
-0,20\end{array}$ & $\begin{array}{c}2307,91 \\
498,44 \\
152,67 \\
52,16\end{array}$ & $\begin{array}{c}1758,55 \\
817,33 \\
452,34 \\
264,39\end{array}$ \\
\hline 2 & $-7,31 * 10^{-5}$ & 0,257 & 244,8 & $\begin{array}{l}1 \\
2 \\
3 \\
4\end{array}$ & $\begin{array}{l}-76,52 \\
-7,69 \\
-1,30 \\
-0,26\end{array}$ & $\begin{array}{c}2369,20 \\
508,33 \\
155,70 \\
53,19\end{array}$ & $\begin{array}{c}19614,61 \\
9115,29 \\
5044,78 \\
2948,63\end{array}$ \\
\hline 3 & $-4,05^{*} 10^{-4}$ & 1,100 & 194,5 & $\begin{array}{l}1 \\
2 \\
3 \\
4\end{array}$ & $\begin{array}{c}-423,96 \\
-42,5 \\
-7,2 \\
-1,41\end{array}$ & $\begin{array}{l}10074,21 \\
2173,77 \\
666,41 \\
227,68\end{array}$ & $\begin{array}{l}15580,75 \\
7241,54 \\
4007,73 \\
2342,49\end{array}$ \\
\hline 4 & $-4,12 * 10^{-7}$ & 0,110 & 360,4 & $\begin{array}{l}1 \\
2 \\
3 \\
4\end{array}$ & $\begin{array}{c}-0,430 \\
-0,043 \\
-0,007 \\
-0,0014\end{array}$ & $\begin{array}{c}1007,42 \\
219,31 \\
67,16 \\
22,95\end{array}$ & $\begin{array}{c}28873,87 \\
13420,56 \\
7427,42 \\
4341,28\end{array}$ \\
\hline 5 & $-1.86^{*} 10^{-4}$ & 0,570 & 385,2 & $\begin{array}{l}1 \\
2 \\
3 \\
4\end{array}$ & $\begin{array}{c}-194,71 \\
-19,55 \\
-3,31 \\
-0,65\end{array}$ & $\begin{array}{c}5220,27 \\
1130,36 \\
346,53 \\
118,39\end{array}$ & $\begin{array}{c}30857,09 \\
14338,25 \\
7935,31 \\
460,33\end{array}$ \\
\hline 6 & $-1,42 * 10^{-4}$ & 0,378 & $-28,15$ & $\begin{array}{l}1 \\
2 \\
3 \\
4\end{array}$ & $\begin{array}{c}-148,64 \\
-14,91 \\
-2,53 \\
-0,496 \\
\end{array}$ & $\begin{array}{c}3461,86 \\
749,19 \\
229,75 \\
78,49\end{array}$ & $\begin{array}{c}-2256,17 \\
-1046,69 \\
-579,28 \\
-33,60\end{array}$ \\
\hline
\end{tabular}

Примітка. Номер двигуна відповідає типу, наведеному у табл.2.

3 урахуванням сил опору руху автомобіля диференціальне рівняння записується у вигляді [9]:

$$
\frac{\mathrm{dv}}{\mathrm{dt}} \mathrm{m}_{\mathrm{a}} \delta_{\mathrm{o} \sigma}=\mathrm{A}_{1} \mathrm{v}^{2}+\mathrm{B}_{1} \mathrm{v}+\mathrm{C}_{1}-\mathrm{P}_{0}\left(\mathrm{v}, \mathrm{v}^{2}\right) \pm \mathrm{G}_{\mathrm{a}} \sin \alpha
$$

де $\mathrm{P}_{0}\left(\mathrm{v}, \mathrm{v}^{2}\right)$ - сили опору кочення і повітря автомобіля;

$\alpha$ - кут підйому (спуску) дороги.

Рівняння (7) використовують для розв'язання задач, що пов'язані як з усталеним рухом АТЗ (тоді ліва частина рівняння дорівнює нулю, і диференційне рівняння перетворюється в алгебраїчне), так і з несталим рухом (прискорений рух, уповільнений рух). Рівняння (7) дозволяє визначити різні показники тягово-швидкісних властивостей як тих, які нормовані, так і тих, що рекомендовані різними дослідниками, зокрема такими, що наведені у роботі [9]:

1. Швидкісна характеристика «розгін-вибіг».

2. Швидкісна характеристика на останній і передостанній передачах.

3. Швидкісна характеристика на дорозі зі змінним поздовжнім профілем. 
4. Максимальна швидкість.

5. Прискорення при розгоні.

6. Умовна максимальна швидкість.

7. Час розгону на шляху 400 i 1000 м.

8. Час розгону до заданої швидкості.

9. Мінімальна стійка швидкість.

10. Максимальний долаємий підйом.

11. Усталена швидкість на затяжних підйомах.

12. Сила тяги на гаку.

13. Довжина динамічно долаємого підйому.

Вище наведені показники тягово-швидкісних властивостей при роботі автомобіля 3 різними двигунами визначимо за методикою, наведеною в роботі [7]. Основні розрахункові формули для визначення показників тягово-швидкісних властивостей автомобіля наведені у табл. 4.

Таблиця 4 - Основні розрахункові формули для визначення показників тягово-швидкісних властивостей автомобіля [10]

\begin{tabular}{|c|c|}
\hline Параметр & Розрахункова формула \\
\hline 1 & 2 \\
\hline $\begin{array}{l}\text { Рівняння руху при } \\
\text { розгоні }\end{array}$ & $\frac{d V}{d t} m_{a} \delta_{o}=a_{i} V^{2}+b V+c_{i}$ \\
\hline Час розгону, с & $\tau=M_{a} \delta_{\circ} \int_{V_{\mathrm{H}}}^{V_{\mathrm{K}}} \frac{d V}{a V^{2}+b V+c_{i}}$ \\
\hline Шлях розгону, м & $S=m_{a} \cdot \delta_{o} \cdot\left\{\left.\frac{1}{2 a_{i}} \ln \left|a_{i} V^{2}+b V+c_{i}\right|\right|_{V_{\mathrm{H}}} ^{V_{\mathrm{K}}}-\frac{b_{i}}{2 \cdot a_{i}} \int_{V_{\mathrm{H}}}^{V_{\mathrm{K}}} \frac{d V}{a_{i} V^{2}+b V+c_{i}}\right\}$ \\
\hline $\begin{array}{l}\text { Рівняння руху при } \\
\text { вибігу }\end{array}$ & $\frac{d V}{d t} \cdot m_{a} \cdot \delta_{o}^{\prime}=-m_{a} \cdot g\left(f_{0} K_{f} V\right)-K_{\mathrm{B}} \cdot F \cdot V^{2}-P_{f x}$ \\
\hline \multirow[t]{2}{*}{$\begin{array}{l}\text { Мінімальна усталена } \\
\text { швидкість, м/с }\end{array}$} & $V_{\min y}=-\frac{m_{a} g f_{0} A_{i}-K_{\mathrm{B}} F C_{i}}{m_{a} g K_{f} A_{i}-K_{\mathrm{B}} F B_{i}}+$ \\
\hline & $+\sqrt{\left(\frac{m_{a} g f_{0} A_{i}-K_{\mathrm{B}} F C_{i}}{m_{a} g K_{f} A_{i}-K_{\mathrm{B}} F B_{i}}\right)^{2}-\frac{m_{a} g\left(f_{0} B_{i}-K_{f} C_{i}\right)}{m_{a} g K_{f} A_{i}-K_{\mathrm{B}} F B_{i}}}$ \\
\hline $\begin{array}{l}\text { Максимальна } \\
\text { швидкість, м/с }\end{array}$ & $V_{\max }=\frac{-b_{i}-\sqrt{b_{i}^{2}-4 a_{i} c_{i}}}{2 a_{i}}$ \\
\hline $\begin{array}{l}\text { Середня швидкість } \\
\text { на швидкісній } \\
\text { дорозі, м/с }\end{array}$ & $V_{c}=\frac{\sum S_{i}}{\sum t_{i}}$ \\
\hline $\begin{array}{l}\text { Максимальне } \\
\text { прискорення при } \\
\text { розгоні, м/ } \mathrm{c}^{2}\end{array}$ & $j_{\max }=\frac{1}{G_{a} \delta_{i}}\left(c_{i}-\frac{b_{i}^{2}}{4 a_{i}}\right)$ \\
\hline $\begin{array}{l}\text { Середнє } \\
\text { прискорення при } \\
\text { розгоні, м/ } \mathrm{c}^{2}\end{array}$ & $j_{c p i}=\frac{1}{G_{a} \delta_{i}}\left[\frac{a_{i}}{3}\left(V_{\mathrm{K}}^{2}+V_{\mathrm{K}} V_{\mathrm{H}}+V_{\mathrm{H}}^{2}\right)+\frac{b_{i}}{2}\left(V_{\mathrm{K}}+V_{\mathrm{H}}\right)+c_{i}\right]$ \\
\hline $\begin{array}{l}\text { Максимальний } \\
\text { долаємий підйом }\end{array}$ & $\sin \alpha_{\max }=\frac{1}{G_{a} \delta}\left(C_{i}-G_{a} g f_{0} \cos \alpha-\frac{\left(B_{i}-G_{a} g K_{f} \cos \alpha\right)^{2}}{4 A_{i}}\right)$ \\
\hline $\begin{array}{l}\text { Швидкість на } \\
\text { підйомі, м/с }\end{array}$ & $V_{y c m}=\frac{-b_{i}-\sqrt{b_{i}^{2}-4 a_{i} c_{i}}}{2 a_{i}}$ \\
\hline $\begin{array}{l}\text { Максимальна } \\
\text { сила тяги на гаку, H }\end{array}$ & $P_{\mathrm{KP}_{\max }}=C_{i}-\frac{b_{i}^{2}}{4 a_{i}}$ \\
\hline
\end{tabular}




\begin{tabular}{|c|c|}
\hline $\begin{array}{l}\text { Середня швидкість } \\
\text { на маршруті, м/с }\end{array}$ & $V_{c}=\frac{0,27 N_{y d} \eta_{m} \sum_{i=1}^{n} K_{i} d_{i}}{\frac{\gamma_{p i N} \sum K_{i} d_{i}}{l_{i}}}$ \\
\hline Коефіцієнти рівнянь & 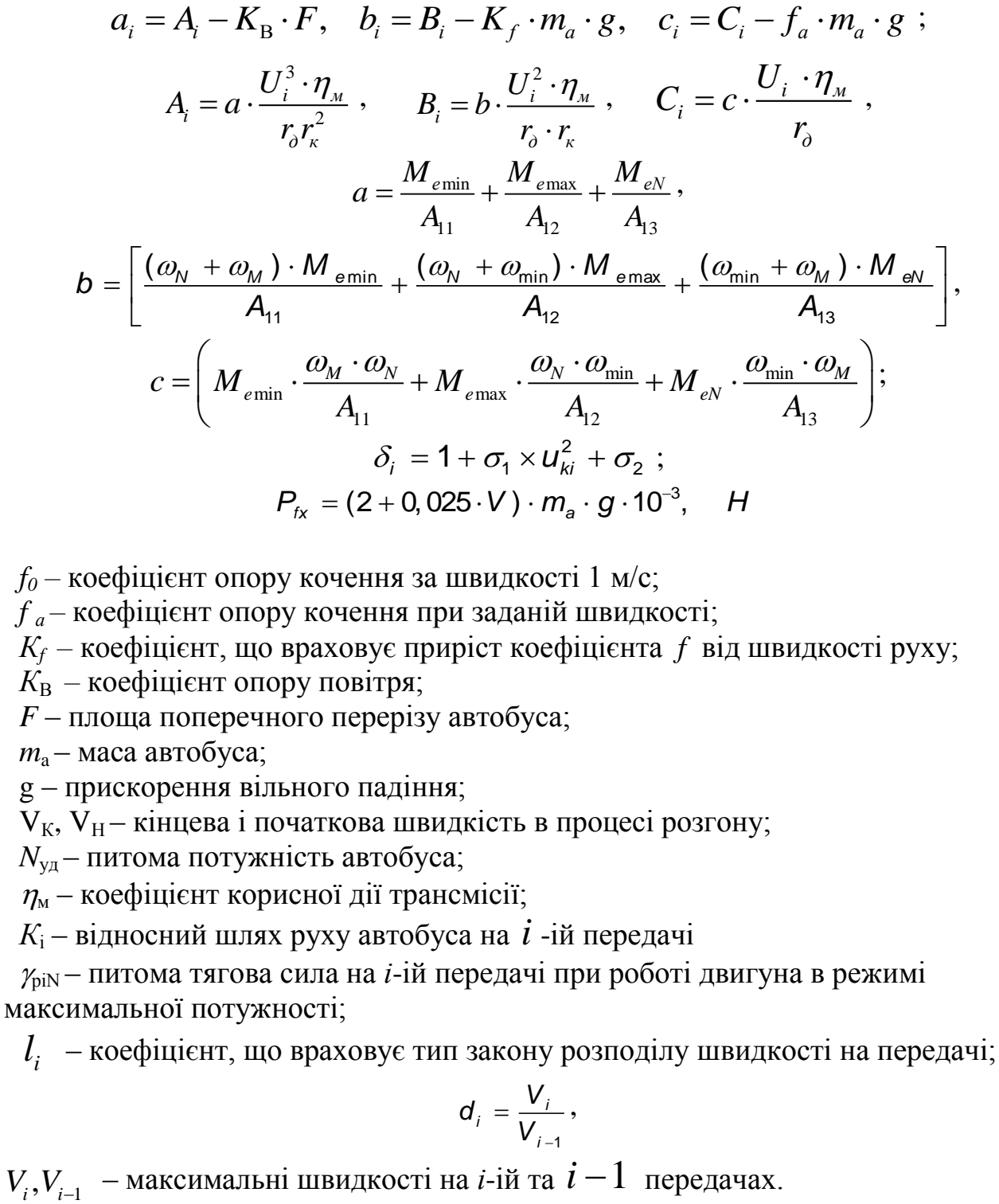 \\
\hline
\end{tabular}

У відповідності з наведеним алгоритмом розрахунку визначені показники тягово-швидкісних властивостей автомобіля за різних двигунів, табл. 5. Зважаючи на те, що потужності двигунів різняться між собою, то і максимальна їх швидкість буде різною. Цю швидкість можна визначити 3 рівняння потужнісного балансу автомобіля, що представлене у вигляді графіка, рис. 1. 


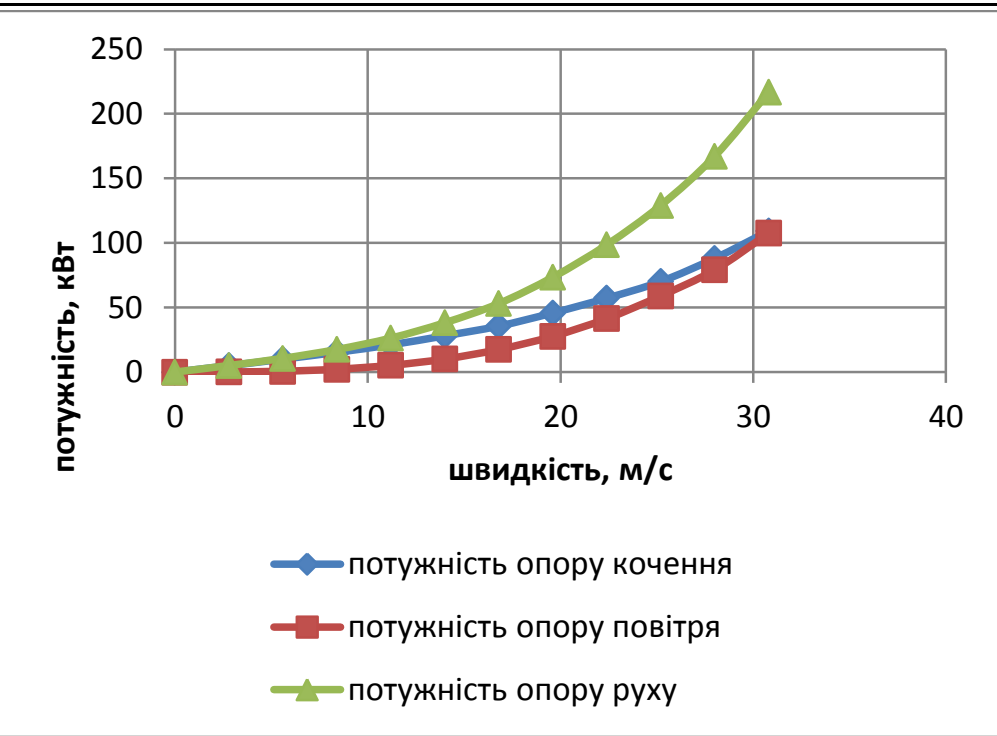

Рисунок 1 - Залежність потужностей опору кочення і повітря, а також сумарної потужності опору від швидкості автомобіля

Для автомобіля з різними двигунами вона склала: 25 м/с для автомобіля 3 двигунами 3М3; 26,3 м/с - 3 двигунами General Motors; 27,5 - 3 двигунами IVECO Tector P4; 27,9- двигунами Д245.30E2; 25,7-з двигуном DEUTZ TCD 2013 L44V; 26,2 - з двигунами DEUTZ TCD 2013 L44V i D 914L3.

У зв'язку з цим розганяння автомобіля з різними двигунами визначалося до швидкості 25 м/с (90 км/год).

У табл. 5 наведені значення окремих параметрів, необхідних для розрахунку показників тяговошвидкісних властивостей, зокрема: $P_{M \max }, P_{M N}, V_{M}, V_{N} ; J_{M}, J_{N}$ - тягова сила на ведучих колесах, швидкість і прискорення автомобіля на $i$-ій передачі за частоти обертання колінчастого валу двигуна, що відповідає максимальному крутному моменту і максимальній потужності; $P f, P w$ - сили опору кочення і повітря; T, S - час і шлях розгону автомобіля на і-ій передачі.

Таблиця 5 - Вихідні параметри для розрахунку показників тягово-швидкісних властивостей автомобіля

\begin{tabular}{|c|c|c|c|c|c|c|c|c|c|c|c|}
\hline \multirow[b]{2}{*}{$\begin{array}{l}\text { Двиг } \\
\text { ун }\end{array}$} & \multicolumn{11}{|c|}{ Параметри } \\
\hline & $\underset{\mathrm{H}}{P_{M \max },}$ & $\begin{array}{l}V_{M}, \\
\mathrm{M} / \mathrm{c}\end{array}$ & $P_{M N}, \mathrm{H}$ & $\begin{array}{l}V_{N}, \\
\mathbf{M} / \mathrm{c}\end{array}$ & $\begin{array}{c}\text { Пере- } \\
\text { дача }\end{array}$ & $P f, \mathrm{H}$ & $P w, \mathrm{H}$ & $\begin{array}{r}J_{M} \\
M / c^{2}\end{array}$ & $\begin{array}{c}J_{N}, \\
M / c^{2}\end{array}$ & $\mathrm{~T}, \mathrm{c}$ & $\underset{M}{S}$ \\
\hline 1 & $\begin{array}{c}45511 \\
21150 \\
11705 \\
6842 \\
5474\end{array}$ & $\begin{array}{c}2,1 \\
4,54 \\
8,2 \\
14,02 \\
17,53\end{array}$ & $\begin{array}{c}36537 \\
16980 \\
9387 \\
5487 \\
4390\end{array}$ & $\begin{array}{c}3,0 \\
6,5 \\
11,7 \\
20,0 \\
25,0\end{array}$ & $\begin{array}{c}1 \\
2 \\
3 \\
4 \\
5(0,8)\end{array}$ & $\begin{array}{l}1750 \\
1750 \\
1900 \\
2400 \\
2710\end{array}$ & $\begin{array}{c}0 \\
0 \\
400 \\
1500 \\
1680\end{array}$ & $\begin{array}{c}1,31 \\
1,15 \\
0,72 \\
0,396 \\
0,09\end{array}$ & $\begin{array}{c}1,04 \\
0,90 \\
0,61 \\
0,29 \\
0\end{array}$ & $\begin{array}{c}1,8 \\
3 \\
6,5 \\
10,5 \\
166\end{array}$ & $\begin{array}{c}4,6 \\
16,5 \\
65,8 \\
180 \\
3486\end{array}$ \\
\hline 2 & $\begin{array}{l}81647 \\
37943 \\
20999 \\
12275 \\
8249\end{array}$ & $\begin{array}{c}1,55 \\
3,36 \\
6,09 \\
10,37 \\
15,43\end{array}$ & $\begin{array}{c}69469 \\
28102 \\
15535 \\
9081 \\
6102\end{array}$ & $\begin{array}{l}2,46 \\
5,33 \\
9,69 \\
16,8 \\
25,0\end{array}$ & $\begin{array}{c}1 \\
2 \\
3 \\
4 \\
5(0,67 \\
2)\end{array}$ & $\begin{array}{l}1750 \\
1750 \\
1850 \\
2100 \\
2710\end{array}$ & $\begin{array}{c}0 \\
0 \\
400 \\
900 \\
1680\end{array}$ & $\begin{array}{l}2,39 \\
1,56 \\
1,34 \\
0,72 \\
0,30\end{array}$ & $\begin{array}{l}2,02 \\
1,56 \\
0,96 \\
0,47 \\
0,14\end{array}$ & $\begin{array}{c}1,42 \\
1,9 \\
4,2 \\
9,7 \\
45,5\end{array}$ & $\begin{array}{c}2,8 \\
8,6 \\
33,2 \\
118 \\
808\end{array}$ \\
\hline
\end{tabular}


() Сахно В.П., Ященко Д.М., Диких О.В., Стельмащук В.В., Онищук В.П. 2020

\begin{tabular}{|c|c|c|c|c|c|c|c|c|c|c|c|}
\hline 3 & $\begin{array}{l}87526 \\
40675 \\
22510 \\
13159 \\
8843\end{array}$ & $\begin{array}{c}1,55 \\
3,36 \\
6,09 \\
10,37 \\
15,43\end{array}$ & $\begin{array}{c}73777 \\
29844 \\
16498 \\
9969 \\
6480\end{array}$ & $\begin{array}{l}2,46 \\
5,33 \\
9,69 \\
16,8 \\
25,0\end{array}$ & $\begin{array}{c}1 \\
2 \\
3 \\
4 \\
5(0,67 \\
2)\end{array}$ & $\begin{array}{l}1750 \\
1750 \\
1850 \\
2100 \\
2710\end{array}$ & $\begin{array}{c}0 \\
0 \\
400 \\
900 \\
1680\end{array}$ & $\begin{array}{l}2,56 \\
2,30 \\
1,47 \\
0,79 \\
0,35\end{array}$ & $\begin{array}{l}2,15 \\
1,66 \\
1,03 \\
0,54 \\
0,16\end{array}$ & $\begin{array}{c}1,41 \\
2,11 \\
5,8 \\
10,0 \\
38,3\end{array}$ & $\begin{array}{c}2,82 \\
9,3 \\
44,1 \\
135 \\
766\end{array}$ \\
\hline 4 & $\begin{array}{c}91377 \\
42468 \\
23500 \\
13738 \\
8243\end{array}$ & $\begin{array}{c}1,38 \\
3,29 \\
5,42 \\
9,23 \\
13,27\end{array}$ & $\begin{array}{c}77023 \\
31157 \\
17224 \\
10408 \\
6040\end{array}$ & $\begin{array}{l}2,19 \\
4,74 \\
8,62 \\
14,9 \\
25,0\end{array}$ & $\begin{array}{c}1 \\
2 \\
3 \\
4 \\
5(0,60 \\
\quad)\end{array}$ & $\begin{array}{l}1750 \\
1750 \\
1850 \\
2100 \\
2710\end{array}$ & $\begin{array}{c}0 \\
0 \\
400 \\
900 \\
1680\end{array}$ & $\begin{array}{l}2,68 \\
2,41 \\
1,54 \\
0,84 \\
0,30\end{array}$ & $\begin{array}{l}2,25 \\
1,74 \\
1,08 \\
0,58 \\
0,13\end{array}$ & $\begin{array}{c}1,3 \\
1,7 \\
3,5 \\
9,2 \\
41,6\end{array}$ & $\begin{array}{c}1,1 \\
7,0 \\
24,5 \\
111 \\
765\end{array}$ \\
\hline 5 & $\begin{array}{c}70909 \\
32955 \\
18236 \\
10661 \\
6130\end{array}$ & $\begin{array}{c}1,56 \\
3,72 \\
6,12 \\
10,43 \\
15,64\end{array}$ & $\begin{array}{c}59770 \\
24188 \\
13366 \\
8077 \\
4492\end{array}$ & $\begin{array}{c}2,10 \\
4,55 \\
8,28 \\
14,3 \\
5 \\
25,0\end{array}$ & $\begin{array}{c}1 \\
2 \\
3 \\
4 \\
5(0,57 \\
5)\end{array}$ & $\begin{array}{l}1750 \\
1750 \\
1850 \\
2100 \\
2710\end{array}$ & $\begin{array}{c}0 \\
0 \\
400 \\
900 \\
1680\end{array}$ & $\begin{array}{l}2,07 \\
1,85 \\
1,16 \\
0,60 \\
0,14\end{array}$ & $\begin{array}{l}1,74 \\
1,33 \\
0,81 \\
0,40 \\
0,01\end{array}$ & $\begin{array}{c}1,3 \\
1,52 \\
3,15 \\
9,2 \\
133\end{array}$ & $\begin{array}{c}2,4 \\
6,3 \\
22,7 \\
114 \\
2367\end{array}$ \\
\hline 6 & $\begin{array}{c}92565 \\
43020 \\
23806 \\
13917 \\
8002\end{array}$ & $\begin{array}{c}1,56 \\
3,72 \\
6,12 \\
10,43 \\
15,64\end{array}$ & $\begin{array}{c}78024 \\
31562 \\
17448 \\
10543 \\
5864\end{array}$ & $\begin{array}{c}2,10 \\
4,55 \\
8,28 \\
14,3 \\
5 \\
25,0\end{array}$ & $\begin{array}{c}1 \\
2 \\
3 \\
4 \\
5(0,57 \\
5)\end{array}$ & $\begin{array}{l}1750 \\
1750 \\
1850 \\
2100 \\
2710\end{array}$ & $\begin{array}{c}0 \\
0 \\
400 \\
900 \\
1680\end{array}$ & $\begin{array}{l}2,72 \\
2,44 \\
1,56 \\
0,85 \\
0,28\end{array}$ & $\begin{array}{l}2,52 \\
1,76 \\
1,10 \\
0,59 \\
0,10\end{array}$ & $\begin{array}{c}1,2 \\
1,4 \\
2,6 \\
6,5 \\
49,3\end{array}$ & $\begin{array}{c}2,1 \\
5,8 \\
19,3 \\
80,6 \\
1077\end{array}$ \\
\hline
\end{tabular}

У табл. 6 наведені результати розрахунку оціночних показників тягово-швидкісних властивостей автомобіля 3 двигунами, що розглядаються. Порівняння автопоїздів за показниками тягово-швидкісних властивостей виконано за допомогою відносних показників [7]

$$
k_{i}=\frac{P_{i}}{P_{e}},
$$

де $P_{\mathrm{i}}-$ значення показника для автомобіля з різними двигунами;

$P_{\mathrm{e}}-$ значення показника для еталонного автомобіля, кожний показник якого $є$ кращим із показників автомобіля з двигунами, що розглядаються.

У табл. 6 наведені результати розрахунку абсолютних і відносних показників тяговошвидкісних властивостей БТЗ-70 з двигунами, що розглядаються.

Таблиця 6- Показники тягово-швидкісних властивостей БТР-70

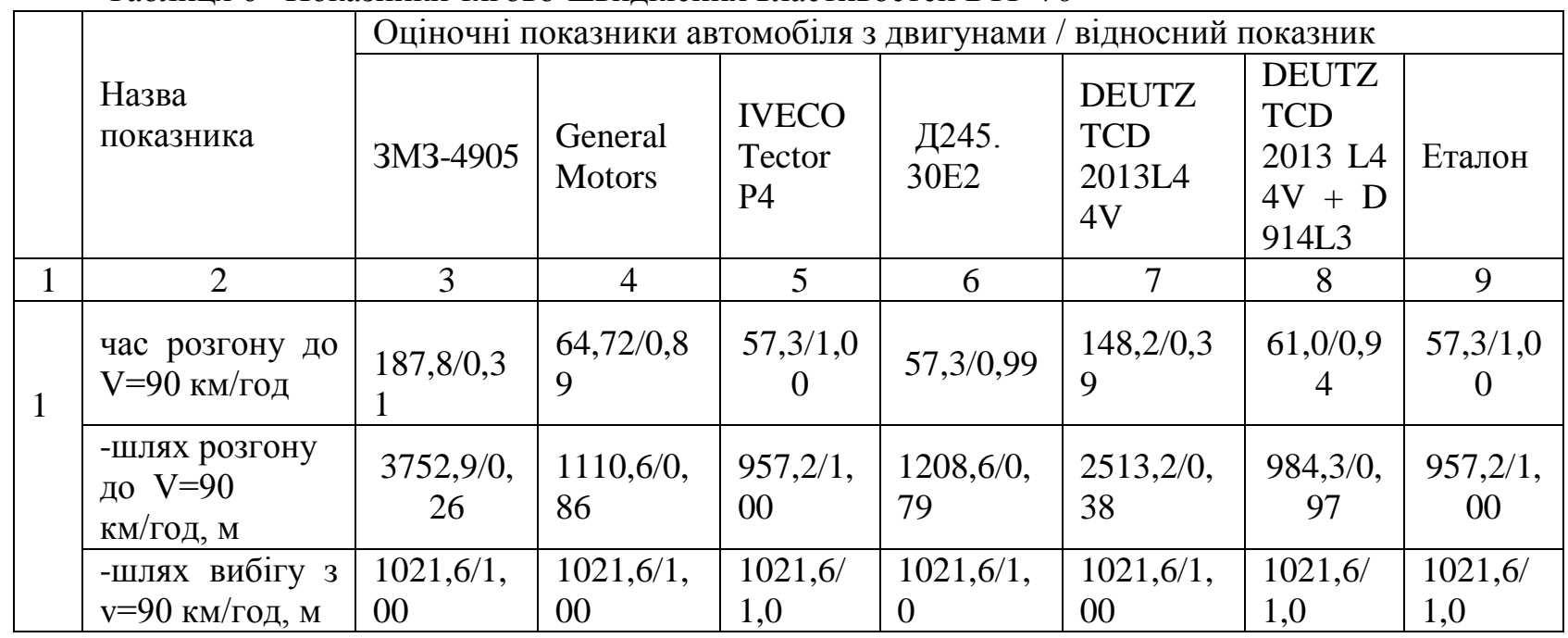


() Сахно В.П., Ященко Д.М., Диких О.В., Стельмащук В.В., Онищук В.П. 2020

\begin{tabular}{|c|c|c|c|c|c|c|c|c|}
\hline & \multirow[b]{2}{*}{$\begin{array}{l}\text { Назва } \\
\text { показника }\end{array}$} & \multicolumn{7}{|c|}{ Оціночні показники автомобіля з двигунами / відносний показник } \\
\hline & & 3М3-4905 & $\begin{array}{l}\text { General } \\
\text { Motors }\end{array}$ & $\begin{array}{l}\text { IVECO } \\
\text { Tector } \\
\text { P4 }\end{array}$ & $\begin{array}{l}\text { Д245. } \\
\text { 30Е2 }\end{array}$ & $\begin{array}{l}\text { DEUTZ } \\
\text { TCD } \\
2013 \mathrm{~L} 4 \\
4 \mathrm{~V}\end{array}$ & $\begin{array}{l}\text { DEUTZ } \\
\text { TCD } \\
2013 \text { L4 } \\
4 \mathrm{~V}+\mathrm{D} \\
914 \mathrm{~L} 3\end{array}$ & Еталон \\
\hline 1 & 2 & 3 & 4 & 5 & 6 & 7 & 8 & 9 \\
\hline \multirow{4}{*}{2} & $\begin{array}{c}\text { - час розгону } \\
\text { на останній } \\
\text { передачі, с }\end{array}$ & $166 / 0,23$ & $45,5 / 0,84$ & $\begin{array}{c}38,3 / 1,0 \\
0\end{array}$ & $41,6 / 0,92$ & $133 / 0,29$ & $\begin{array}{c}49,3 / 0,7 \\
8\end{array}$ & $\begin{array}{c}38,3 / 1,0 \\
0\end{array}$ \\
\hline & $\begin{array}{l}\text { - шлях розгону } \\
\text { на останній } \\
\text { передачі, м }\end{array}$ & $3486 / 0,22$ & $808 / 0,95$ & $766 / 1,0$ & $1065 / 0,72$ & $2367 / 0,32$ & $\begin{array}{l}1077 / 0, \\
71\end{array}$ & $766 / 1,0$ \\
\hline & $\begin{array}{l}\text { - час розгону } \\
\text { на } \\
\text { передостанній } \\
\text { передачі, с }\end{array}$ & $10,5 / 0,62$ & $9,7 / 0,67$ & $\begin{array}{c}10,0 / 0,6 \\
5\end{array}$ & $9,1 / 0,71$ & $9,2 / 0,71$ & $6,5 / 1,00$ & $6,5 / 1,00$ \\
\hline & $\begin{array}{l}\text { - шлях розгону } \\
\text { на } \\
\text { передостанній } \\
\text { передачі, м }\end{array}$ & $180 / 0,62$ & $118 / 0,68$ & $\begin{array}{l}135 / 0,6 \\
5\end{array}$ & $111 / 0,71$ & $114,8 / 0,7$ & $80,6 / 1,0$ & $80,6 / 1,0$ \\
\hline 3 & $\begin{array}{l}\text { середня } \\
\text { швидкість, м/с }\end{array}$ & $\begin{array}{c}15,07 / 0,7 \\
5 \\
\end{array}$ & $\begin{array}{c}19,26 / 0,9 \\
6 \\
\end{array}$ & $\begin{array}{c}19,53 / 0 \\
97 \\
\end{array}$ & $\begin{array}{c}20,06 / 1,0 \\
0 \\
\end{array}$ & $\begin{array}{c}19,31 / 0,9 \\
6 \\
\end{array}$ & $\begin{array}{c}19,34 / 0 \\
96 \\
\end{array}$ & $\begin{array}{c}20,06 / 1, \\
00\end{array}$ \\
\hline 4 & $\begin{array}{l}\text { максимальна } \\
\text { швидкість за } \\
\text { енеретичними } \\
\text { можливостями, } \\
\text { м/с }\end{array}$ & $25,0 / 0,90$ & $26,3 / 0,94$ & $\begin{array}{c}27,5 / 0,9 \\
9\end{array}$ & $27,9 / 1,00$ & $25,7 / 0,92$ & $\begin{array}{c}26,2 / 0,9 \\
4\end{array}$ & $\begin{array}{c}27,9 / 1,0 \\
0\end{array}$ \\
\hline 5 & 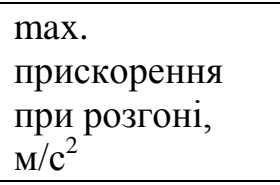 & $1,31 / 0,48$ & $2,39 / 0,88$ & $\begin{array}{c}2,56 / 0,9 \\
4\end{array}$ & $2,68 / 0,99$ & $2,07 / 0,76$ & $2,72 / 1,0$ & $2,72 / 1,0$ \\
\hline 6 & $\begin{array}{l}\text { умовна } \\
\text { максимальна } \\
\text { швидкість, м/с } \\
\end{array}$ & $28,8 / 0,90$ & $30,5 / 0,95$ & $\begin{array}{c}31,6 / 0,9 \\
8\end{array}$ & $32,1 / 1,00$ & $30,7 / 0,96$ & $\begin{array}{c}30,1 / 0,9 \\
6\end{array}$ & $\begin{array}{c}32,1 / 1,0 \\
0\end{array}$ \\
\hline 7 & $\begin{array}{l}\text { час розгону на } \\
\text { шляху, с: } \\
400 \mathrm{M}\end{array}$ & $\begin{array}{c}23,14 / 0,8 \\
9\end{array}$ & $\begin{array}{c}22,54 / 0,9 \\
1\end{array}$ & $\begin{array}{c}22,12 / 0 \\
93\end{array}$ & $\begin{array}{c}20,58 / 1,0 \\
0\end{array}$ & $\begin{array}{c}22,42 / 0,9 \\
2\end{array}$ & $\begin{array}{c}20,84 / 0 \\
99\end{array}$ & $\begin{array}{l}20,58 / 1, \\
00\end{array}$ \\
\hline & 1000 м. & 60,5 & - & - & 55,6 & 54,8 & - & - \\
\hline 8 & $2000 \mathrm{M}$ & 122,27 & - & - & 118,27 & 115,76 & - & - \\
\hline 9 & $\begin{array}{l}\text { мінімальна } \\
\text { стійка } \\
\text { швидкість, м/с }\end{array}$ & $2,10 / 0,66$ & $1,55 / 0,89$ & $\begin{array}{c}1,55 / 0,8 \\
9\end{array}$ & $1,38 / 1,00$ & $1,55 / 0,89$ & $\begin{array}{c}1,55 / 0,8 \\
9\end{array}$ & $\begin{array}{c}1,38 / 1,0 \\
0\end{array}$ \\
\hline $\begin{array}{l}1 \\
0\end{array}$ & $\begin{array}{l}\text { максимальний } \\
\text { долаємий } \\
\text { підйом, \% }\end{array}$ & $\begin{array}{l}21,66 / 0,4 \\
0\end{array}$ & $\begin{array}{l}49,34 / \\
0,91\end{array}$ & $\begin{array}{l}49,85 / 0 \\
92\end{array}$ & $\begin{array}{l}53,17 / 0,9 \\
8\end{array}$ & $\begin{array}{l}37,19 / 0,6 \\
9\end{array}$ & $\begin{array}{l}54,26 / 1 \\
00\end{array}$ & $\begin{array}{l}54,26 / 1, \\
00\end{array}$ \\
\hline $\begin{array}{l}1 \\
1\end{array}$ & $\begin{array}{l}\text { усталена } \\
\text { швидкість на } \\
\text { затяжних } \\
\text { підйомах }(3 \%) \text {, } \\
\text { м/с } \\
\end{array}$ & $\begin{array}{c}14,87 / 0,6 \\
5\end{array}$ & $\begin{array}{c}21,23 / 0,9 \\
3\end{array}$ & $\begin{array}{c}22,02 / 0 \\
97\end{array}$ & $\begin{array}{c}22,39 / 0,9 \\
8\end{array}$ & $\begin{array}{c}21,98 / 0,9 \\
8\end{array}$ & $\begin{array}{c}22,76 / 1 \\
00\end{array}$ & $\begin{array}{c}22,76 / 1, \\
00\end{array}$ \\
\hline $\begin{array}{l}1 \\
2\end{array}$ & $\begin{array}{c}\text { max. сила тяги } \\
\text { на гаку, кН }\end{array}$ & $\begin{array}{c}43,76 / 0,4 \\
8\end{array}$ & $\begin{array}{c}82,90 / 0,9 \\
2\end{array}$ & $\begin{array}{c}85,78 / 0 \\
94\end{array}$ & $\begin{array}{c}89,63 / 0,9 \\
9\end{array}$ & $\begin{array}{c}69,16 / 0,7 \\
6\end{array}$ & $\begin{array}{c}90,82 / 1 \\
00\end{array}$ & $\begin{array}{l}90,82 / 1, \\
00\end{array}$ \\
\hline
\end{tabular}


() Сахно В.П., Ященко Д.м., Диких О.В., Стельмащук В.В., Онищук В.П. 2020

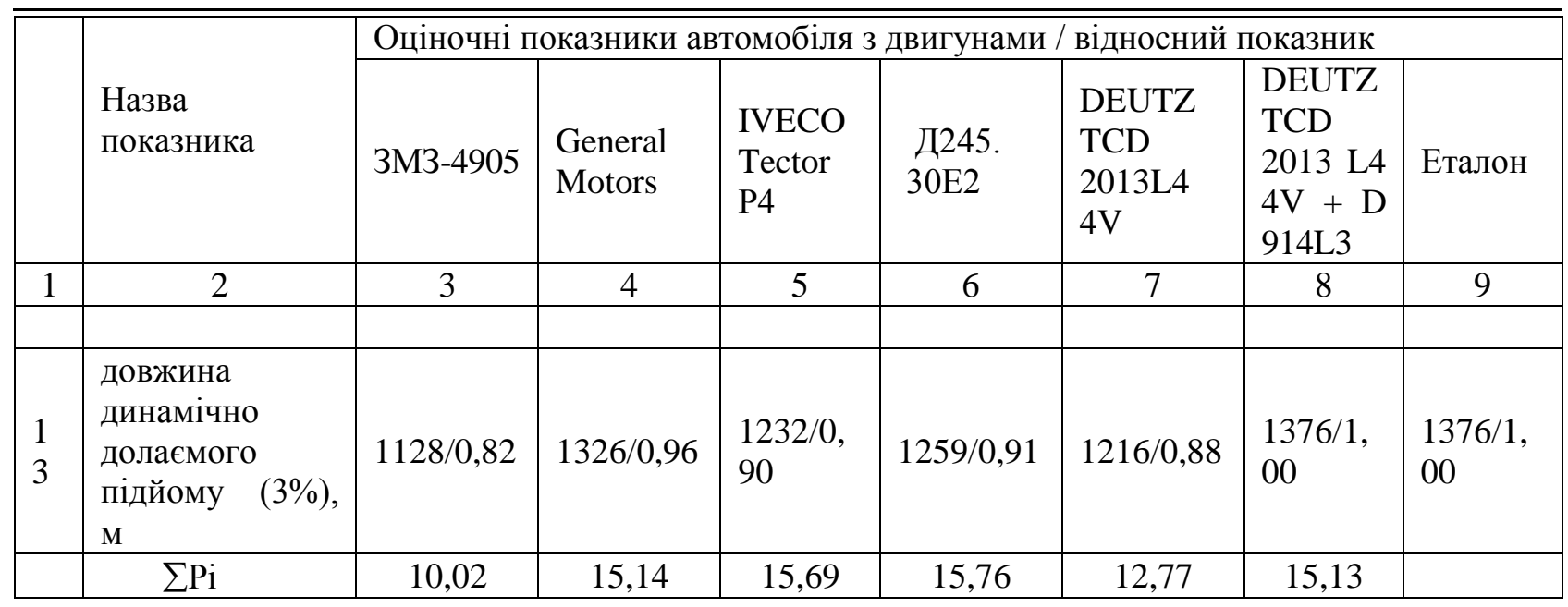

Як слідує з табл. 6, показники тягово-швидкісних властивостей автомобіля з двигунами IVECO Tector P4, Д245.30E2 і двома двигунами DEUTZ TCD 2013 майже однакові. При цьому сумарний відносний показник тягово-швидкісних властивостей змінюється від найбільшого (двигуни Д245.30E2) до найменшого (два двигуни DEUTZ TCD 2013) в межах 4\%, не зважаючи на те, що їх потужність змінюється на 11,3\%. Тому вибір кращого типу двигуна при переобладнанні БТР-70 повинен проводитися з урахуванням інших показників, зокрема, паливної економічності.

\section{ОБГОВОРЕННЯ РЕЗУЛЬТАТІВ ДОСЛІДЖЕННЯ}

При переобладнанні автомобілів заміні підлягає один з базових його агрегатів, зокрема, у розглянутому випадку заміна двигуна. Проте таке переобладнання не можна вважати доцільним, бо тягово-швидкісні властивості автомобіля визначаються не тільки потужністю двигуна, a i передаточними відношеннями трансмісії. Штатна трансмісія БТР-70 з бензиновими двигунами не сумісна при його оснащенні дизелями. Тому для отримання необхідних показників тяговошвидкісних властивостей БТР-70 потрібно не його переобладнання, а модернізація, тобто заміна системи двигун-трансмісія. Вибору передаточних відношень трансмісії БТР-70 при його оснащенні одним із розглянутих дизелів будуть присвячені подальші дослідження.

\section{ВИСНОВКИ}

Встановлено, що показники тягово-швидкісних властивостей автомобіля з двигунами IVECO Tector P4, Д245.30E2 і двома двигунами DEUTZ TCD 2013 майже однакові. При цьому сумарний відносний показник тягово-швидкісних властивостей змінюється від найбільшого (двигуни Д245.30E2) до найменшого (два двигуни DEUTZ TCD 2013) в межах 4\%, не зважаючи на те, що їх потужність змінюється на 11,3\%. Тому вибір кращого типу двигуна при переобладнанні БТР-70 повинен проводитися з урахуванням інших показників, зокрема, паливної економічності.

\section{ПЕРЕЛІК ДЖЕРЕЛ ПОСИЛАННЯ}

1.http://www.ukrrudprom.com/digest/Radikalnaya_modernizatsiya_Kak_iz_starogo_sovetsko go_BTR

2.Модернізований БТР-70 з двигуном General Motors /https://mil.in.ua/uk/

3. С.П. Мазін, Г.М. Маренко, А.Г. Скиба, В.М. Франков Пропозиції щодо вдосконалення конструкції бронетранспортерів Національної гвардії України/ Міжвузівський збірник "НАУКОВІ НОТАТКИ". Луцьк, 2017. Випуск № 60 (111). - С.156-160.

4. Сахно В.П. та ін. Експлуатаційні властивості автотранспортних засобів. В 3 ч. Ч 1. Динамічність та паливна економічність автотранспортних засобів: [навчальний посібник] /В.П.Сахно, А.П.Костенко, М.І.Загороднов та ін. - Донецьк: Вид-во «Ноулідж» (донецьке відділення), 2014. - 444 c.

5. Сахно В.П. Автомобілі: Тягово-швидкісні властивості та паливна економічність: [навч. посіб.] / В.П. Сахно. Г.Б. Безбородова, М.М. Маяк, С.М. Шарай. - К. : «КВІЦ», 2004. - 174 с.

6. Подригало М.А., Волков В.П., Бобошко А.А., Павленко В.А., Файст В.Л., Клец Д.М., Редько В.В. Динамика автомобиля. - Харьков: Изд-во ХНАДУ, 2008. - 426 с.

7. Сахно В.П. До вибору типа автомобіля-тягача для автопоїзда великої вантажопідйомності / В.П.Сахно, В.М.Поляков, І.С.Мурований, С.М.Шарай //Вісник машинобудування та транспорту: 
науковий журнал /Міністерство освіти і науки України, Вінницький національний технічний університет - Вінниця: ВНТУ, № 2(10), 2019. - С.120-125.

8. Літвінов О.В. Експериментальне оцінювання показників динаміки та опору руху спеціалізованої колісної техніки/Механіка та машинобудування, 2017, №1, с.278-288

9. Литвинов А.С., Фаробин Я.Е. Автомобиль: Теория эксплуатационных свойств: Учебник для вузов по специальности «Автомобили и автомобильное хозяйство». - М.: Машиностроение, 1989. $240 \mathrm{c}$.

10. Фаробин Я.Е., Щупляков В.С. Оценка эксплуатационных свойств автопоездов для междугородных перевозок. М.: Транспорт. 1983. - 200 с.

\section{REFERENCES \\ 1.http://www.ukrrudprom.com/digest/Radikalnaya modernizatsiya_Kak iz starogo_sovetskogo_ BTR}

2. Modernized BTR-70 with General Motors engine /https://mil.in.ua/uk/

3. S.P. Mazin, G.M. Marenko, A.G. Skiba, V.M. Frankov Proposals for improving the design of armored personnel carriers of the National Guard of Ukraine / Interuniversity collection "SCIENTIFIC NOTES". Lutsk, 2017. Issue № 60 (111). - P.156-160.

4. Sakhno V.P. etc. Performance properties of vehicles. In 3 hours. Part 1. Dynamics and fuel economy of vehicles: [textbook] / V.P. Sakhno, A.P. Kostenko, M.I. Zagorodnov and others. - Donetsk: Knowledge Publishing House (Donetsk branch), 2014. - 444 p.

5. Sakhno V.P. Cars: Traction and speed properties and fuel economy: [textbook. aid.] / V.P. Sakhno, G.B. Bezborodova, M.M. Majak, S.M. Sharay. - К.: «КВIЦ», 2004. - 174 c.

6. Podrigalo M.A., Volkov V.P., Boboshko A.A., Pavlenko V.A., Faist V.L., Klets D.M., Redko V.V. Car dynamics. - Kharkiv: KhNADU Publishing House, 2008. - 426 p.

7. Sakhno V.P. To choose the type of tractor for a high-capacity road train / V.P.Sakhno, V.M.Polyakov, I.S.Murovany, S.M.Sharay // Bulletin of Mechanical Engineering and Transport: a scientific journal / Ministry of Education and Science of Ukraine, Vinnytsia National Technical University - Vinnytsia: VNTU, № 2 (10), 2019. - P.120-125.

8. Litvinov O.V. Experimental evaluation of indicators of dynamics and resistance to movement of specialized wheeled vehicles / Mechanics and Mechanical Engineering, 2017, №1, p.278-288.

9. Litvinov A.S., Farobin Ya.E. Car: Theory of operational properties: A textbook for universities in the specialty "Cars and Automotive". - M .: Mashinostroenie, 1989. - $240 \mathrm{~s}$.

10. Farobin Ya.E., Shchuplyakov V.S. Estimation of operational properties of road trains for longdistance transportations. M .: Transport. 1983. - $200 \mathrm{p}$.

\section{Sakhno, D.Jachenko, O. Dykich, V. Stelmashchuk, V. Onyshchuk. To choose the type of engine when modernizing BTR-70}

The paper considers options for retrofitting BTR-70 by installing on the chassis of this car instead of two engines ZMZ-4905 two engines General Motors with a capacity of $103 \mathrm{~kW}$, or two IVECO Tector P4 with a capacity of $110.4 \mathrm{~kW}$, or two engines D245.30E2 with a capacity of $115 \mathrm{~kW}$, or two engines of different power - the power of the main engine DEUTZ TCD $2013 \mathrm{~L} 44 \mathrm{~V} 161 \mathrm{~kW}$ and the power of the additional engine DEUTZ D 914L3 $43 \mathrm{~kW}$.

The comparative analysis is based on the main indicators of traction-velocity properties, obtained by solving the differential equation of motion, the initial data for which are the mass and geometric parameters of the car and operating conditions. The choice of the best variant is made on the basis of comparison of each indicator of traction-speed properties with the standard as which the best indicator from all possible variants is accepted. According to the results of calculations, it is established that the best indicators of traction and speed properties are achieved when installing two engines D245.30E2 on the BTR-70.

However, such conversion can not be considered appropriate, because the traction and speed properties of the car are determined not only by engine power, but also the gear ratio. Regular transmission BTR-70 with gasoline engines is not compatible when equipped with diesels. Therefore, to obtain the necessary indicators of traction and speed properties of the BTR-70 requires not its re-equipment, but modernization, ie replacement of the engine-transmission system. Further research will be devoted to the choice of BTR-70 transmission gear ratios when it is equipped with D245.30E2 diesels.

Keywords: BTR-70, engine, power, modernization, indicator, traction-speed properties, standard, differential equation of motion. 
() Сахно В.П., Ященко Д.М., Диких О.В., Стельмащук В.В., Онищук В.П. 2020

САХНО Володимир Прохорович, доктор технічних наук, професор, завідувач кафедри автомобілів, Національний транспортний університет, svp_40@ukr.net

ЯЩЕНКО Дмитро Миколайович, кандидат технічних наук, доцент, доцент кафедри автомобілів, Національний транспортний університет, e-mail: y_d@ukr.net

ДИКИХ Олександр Вікторович, аспірант кафедри автомобілів, Національний транспортний університет, aleksandrdik@ukr.net

СТЕЛЬМАЩУК Валерій Віталійович, кандидат технічних наук, доцент кафедри автомобілів і транспортних технологій Луцького національного технічного університету, e-mail: Val.stelmashchuk@gmail.com. https://orcid.org/0000-0003-3813-3143.

ОНИЩУК Василь Петрович, кандидат технічних наук, доцент кафедри автомобілів i транспортних технологій, Луцький національний технічний університет, e-mail: Vasyl.Onyshchuk@lutsk-ntu.com.ua, https://orcid.org/0000-0002-5316-408X

Volodymyr SAKHNO, Doctor of Science in Engineering, Professor, Head of Automobiles Department, National Transport University, e-mail: sakhno@ntu.edu.ua

ORCID ID https://orcid.org/0000-0002-5144-7131

Dmytro JACHENKO, PhD. in Engineering, Assoc. Professor, Assoc. Professor of Automobiles Department, National Transport University, e-mail: ע_d@ukr.net

Oleksandr DYKICH, magistr of transport, postgradiate student of Automobiles Department, National Transport University, aleksandrdik@ukr.net

Valery STELMASHCHUK, Ph.D in Engeneering, associate professor of automobiles and transport technologies department, Lutsk National Technical University, e-mail: Val.stelmashchuk@gmail.com. https://orcid.org/0000-0003-3813-3143.

Vasyl ONYSHCHUK, $\mathrm{PhD}$ in Engineering, associate professor of Automobiles and Transport Technologies department, Lutsk National Technical University e-mail: Vasyl.Onyshchuk@lutsk-ntu.com.ua, https://orcid.org/0000-0002-5316-408X

DOI 10.36910/automash.v2i15.401 